\title{
Effects of Leonardite Application on Yield of Broad Beans (Vicia faba L.) under Low Input Rainfed Semi-arid Mediterranean Highland Condition of Turkey
}

\author{
Özge Uçar', Sipan Soysal', Murat Erman ${ }^{1}$
}

10.18805/LR-636

\begin{abstract}
Background: This study was conducted to determine the effects of different doses of leonardite applications on yield and some yield components of spring grown broad beans (Vicia faba L.) in the ecological conditions of Siirt province in 2017 and 2019 in the experimental fields of Siirt University.

Methods: The study was established in a randomized complete block design with three replications. Tested leonardite doses were 0 , 200, 400,600, 800 and $1000 \mathrm{~kg} \mathrm{ha}^{-1}$.

Conclusion: The effect of leonardite doses on all of the investigated properties was found statistically significant. According to the results, plant height, first pod height, number of pods per plant, number of seeds per pod, 100 grain weight and grain yields were varied between $45.7-61.3 \mathrm{~cm}, 10.1-13.2 \mathrm{~cm}, 5.03-8.00$ pieces per plant, 2.63-4.03 pieces per pod, $115.6-131.7 \mathrm{~g}$ and $1659-1808 \mathrm{~kg}$ $\mathrm{ha}^{-1}$, respectively. In terms of all examined properties in this research, $1000 \mathrm{~kg} \mathrm{ha}^{-1}$ leonardite application produced the best result. According to the results obtained from this research, $1000 \mathrm{~kg} \mathrm{ha}^{-1}$ leonardite application was recommended for broad bean cultivation in the semi-arid Mediterranean climate conditions on highlands.
\end{abstract}

Key words: Broad bean, Leonardite, Low input, Vicia faba L., Yield.

\section{INTRODUCTION}

Broad bean (Vicia faba L.) is one of the oldest crop in the world. Globally, it is the third most consumed pulse. Currently 58 countries produce it on large scale (Singh et al., 2013). This protein-rich legume is well adapted to most climatic areas of Europe and widely used for feed and food (Crepon et al., 2010; Paolo et al., 2015). Broad bean is becoming increasingly popular in European agriculture due to economic and environmental reasons. It can be highly productive, but sensitive to drought stress and its yields can vary considerably from season to season (Link et al., 2007). In cool-temperate regions, broad bean is mainly grown as a spring crop despite the higher yield potential of the winter type, due to insufficient winter-hardiness of the present winter genotypes (Arbaoui et al., 2008). It is a cool season multipurpose pulse with potential to be grown at short growth seasons. It is grown in many regions in the world due to its high nutritional value, medicinal effect, and effective biological nitrogen fixation (Cao et al., 2017). Diverse benefits get obtained in ecosystems integrating broad bean in cropping systems (Etemadi et al., 2019).

Organic fertilizer or soil amendment usage is an important component for sustainable agriculture (Sun et al., 2016). Leonardite is an oxidized form of lignite obtained from coal mines. It has soil amendment potential and positive effects on crop growth and yield (Akinremi et al., 2000). Leonardite has high amount of readily available organic matter content (Singkham and Ditthakit, 2019). Humic substances extracted from leonardite are considered as bioactive compounds, effecting the plant physiology and
'Department of Field Crops, Siirt University, Faculty of Agriculture, 56100, Siirt, Turkey.

${ }^{2}$ Department of Plant and Animal Production, Siirt University, Kurtalan Vocational High School, 56500, Kurtalan-Siirt, Turkey.

Corresponding Author: Özge Uçar, Department of Field Crops, Siirt University, Faculty of Agriculture, 56100, Siirt, Turkey.

Email: ozgeonderr@hotmail.com

How to cite this article: Uçar, Ö., Soysal, S. and Erman, M. (2021). Effects of Leonardite Application on Yield of Broad Beans (Vicia faba L.) under Low Input Rainfed Semi-arid Mediterranean Highland Condition of Turkey. Legume Research. 44(8): 942-946. DOI: $10.18805 /$ LR-636.

Submitted: 07-06-2021 Accepted: 19-06-2021 Online: 02-08-2021

crop yield (Lingaraju et al., 2016; Barone et al., 2019). Humic substances are abundant in the environment which play important roles in biogeochemical processes like microbial activity, soil aggregation, plant growth, retention and release of nutrients, environmental fate of pollutants and carbon storage. They are flexible, relatively small molecules forming supramolecular structures through weak interactions (Petrov et al., 2017). Humic substances has important roles in the biotic-abiotic interactions of the plant root and soil help plant to adapt to environments. However their mode of action on plants is largely unknown (Kulikova et al., 2016). Leonardite have gained much attention as it can improve soil quality and immobilize herbicides in the subsurface, too (Sakulthaew et al., 2021). 
Effects of Leonardite Application on Yield of Broad Beans (Vicia faba L.) under low input Rainfed Semi-arid Mediterranean...

The objective of this study was to assess the effects of different doses of leonardite on growth and yield traits of broad bean.

\section{MATERIALS AND METHODS Experimental site}

This study was carried out in the growing season of 2017 and 2019 in order to determine the effects of different doses of leonardite on the yield and some yield characteristics of broad bean in Siirt province (semi-arid Mediterranean climate conditions on highlands of South Eastern Anatolia region of Turkey) conditions. Field trials were conducted in experimental fields of Siirt University. The study area soil was clayey-loam, poor in organic matter $(0.9 \%)$, calcareous $(1.6 \%)$, slightly alkaline $(\mathrm{pH} 7.6)$, rich in potassium $(669 \mathrm{~kg}$ $\left.\mathrm{ha}^{-1}\right)$ and poor in phosphorus (31.2 kg ha-1).

\section{Climate of the experimental site}

The trials were carried out in the experimental fields of Siirt University. The average temperature values during the vegetation period in 2017 and 2019 were close to the long term averages. Total precipitation amount and average relative humidity values were above the long-term averages for both years of the study (Table 1).

\section{Plant materials}

Broad bean variety "Salkim" was used in the experiments. Salkim is a registered variety owned by the Aegean Agricultural Research Institute (Turkey). Its erect plant has average $37-70 \mathrm{~cm}$ plant height, $6.0-13.6 \mathrm{~cm}$ first pod height, $131-153 \mathrm{~g} 100$ seed weight, 3.5-4.5 t/ha grain yield and bred for dry consumption (AARI, 2020).

\section{Experimental design, treatments and cultural practices}

The study was carried out in a randomized complete block design with three replications. In the autumn, the trial field was machine plowed, then in the spring, just before the planting, the cultivator and harrow was applied. Before planting, $0,200,400,600,800$ and $1000 \mathrm{~kg} \mathrm{ha}^{-1}$ doses of leonardite were spreaded on the plots and mixed in soil with rake. The leonardite used in the study was containing 35\% organic matter, $40 \%$ total humic + fulvic acid, with $\mathrm{pH} 3-5$ and granular form. Sawing lines were opened manually by a marker. Previous crop was wheat in crop rotation. Hand sowings of broad beans was conducted in the first week of March on four rows at each parcel to five $m$ long rows, with $50 \mathrm{~cm}$ inter-row and $10 \mathrm{~cm}$ intra-row spacing at $4-5 \mathrm{~cm}$ sawing depth similar to Karadavut et al. (2011). The 2018 trial was canceled due to plant emergence problems and re-established in 2019. No irrigation was applied and rainfed cultivation method was followed. Weeds were managed manually. Fungicide spray was applied for the anthracnose disease for three times in 2017 and once in 2019.

\section{Data collection}

For observation and harvesting, border rows from each edges and $0.5 \mathrm{~m}$ from both ends of the plots were cut out. Observations were made on 10 plants selected from the remaining plants in parcels. Parcel harvest was conducted for yield determinations. The plants were harvested in the first week of July when the pods were dried and the grains got hardened. Harvesting and threshing processes were done manually. Plant height, first pod height, number of pods per plant, number of seeds per pod, 100-grain weight and grain yield were investigated.

\section{Data analysis}

The data were subjected to variance analysis and differences between the applications were determined by the $\operatorname{LSD}_{(0.05)}$ test via JMP (version 5.0.1) software program.

\section{RESULTS AND DISCUSSION}

Average values related to the effects of different leonardite doses on yield and some yield characteristics of broad bean plants and LSD groups are given in Table 2. The effect of leonardite doses on plant height was found to be statistically significant for both years of the study. A lineer significant increase were observed for plant heights by increasing application doses of leonardite for both years. Highest plant heights were $60.0 \mathrm{~cm}$ and $61.3 \mathrm{~cm}$ for first and second years, respectively, and were obtained by $1000 \mathrm{~kg} \mathrm{ha}^{-1}$ leonardite application (Table 2). The results obtained in this study were similar to the results of Azcona et al. (2011), Özel (2011)

Table 1: Meteorological data of experimental area*.

\begin{tabular}{|c|c|c|c|c|c|c|c|c|c|}
\hline \multirow{2}{*}{ Months } & \multicolumn{3}{|c|}{$\begin{array}{l}\text { Monthly average temperature } \\
\qquad\left({ }^{\circ} \mathrm{C}\right)\end{array}$} & \multicolumn{3}{|c|}{$\begin{array}{l}\text { Monthly total precipitation } \\
(\mathrm{mm})\end{array}$} & \multicolumn{3}{|c|}{$\begin{array}{c}\text { Monthly average relative } \\
\text { humidity (\%) }\end{array}$} \\
\hline & 2017 & 2018 & $\begin{array}{l}\text { Long year } \\
\text { average }\end{array}$ & 2017 & 2018 & $\begin{array}{l}\text { Long year } \\
\text { average }\end{array}$ & 2017 & 2018 & $\begin{array}{l}\text { Long year } \\
\text { average }\end{array}$ \\
\hline March & 9.6 & 8.3 & 10.1 & 119.2 & 182.0 & 92.3 & 63.9 & 63.5 & 59.2 \\
\hline April & 14.0 & 11.9 & 15.3 & 132.8 & 175.6 & 91.7 & 59.5 & 66.8 & 53.8 \\
\hline May & 19.5 & 21.9 & 20.0 & 74.6 & 64.4 & 69.5 & 51.7 & 41.8 & 49.6 \\
\hline June & 26.9 & 29.1 & 27.0 & 0.0 & 1.2 & 10.8 & 29.5 & 26.5 & 28.7 \\
\hline July & 32.3 & 30.2 & 30.6 & 0.0 & 0.0 & 2.7 & 19.0 & 23.0 & 23.3 \\
\hline Total/ Average & 20.5 & 20.3 & 20.6 & 326.6 & 423.2 & 267.0 & 44.7 & 44.3 & 42.9 \\
\hline
\end{tabular}

* Turkish State Meteorological Service, Siirt Province Official Records. 
Effects of Leonardite Application on Yield of Broad Beans (Vicia faba L.) under low input Rainfed Semi-arid Mediterranean...

and İmamoğlu (2019), who reported increases as a result of leonardite applications.

The effect of leonardite doses on first pod height was found to be statistically significant for both years of the study. A lineer significant increase were observed for plant heights by increasing application doses of leonardite for both years. Highest first pod height values were $12.7 \mathrm{~cm}$ and $13.2 \mathrm{~cm}$ for first and second years, respectively and were obtained by $1000 \mathrm{~kg} \mathrm{ha}^{-1}$ leonardite application (Table 2). Similarly, Öktem et al. (2017) reported that humic acid application increased the first pod height in their study.

The effect of leonardite doses on pod number per plant was found to be statistically significant for both years of the study. A lineer significant increase were observed for pod number per plant by increasing application doses of leonardite for both years. Highest pod number per plants were 7.4 pieces and 8.4 pieces for first and second years, respectively and were obtained by $1000 \mathrm{~kg} \mathrm{ha}^{-1}$ leonardite application (Table 2). Similarly, Öktem et al. (2017) reported that humic acid application increased the pod number per plant.

The effect of leonardite doses on the number of grains per pod was found to be statistically significant for both years of the study (Table 3). The anthracnose disease was occured due to heavy rainfall in the first year which affected the development of plants and reduced the grain number per pod values compared to second year of the study. The effect of leonardite doses on grain number per pod was found to be statistically significant for both years of the study. A lineer significant increase were observed for grain number per pod by increasing application doses of leonardite for both years. Highest grain number per pod were 3.77 pieces and 4.03 pieces for first and second years, respectively, and were obtained by $1000 \mathrm{~kg} \mathrm{ha}^{-1}$ leonardite application (Table 3). Batanay (2016) reported that humic acid increased the number of grains in the plant, similar to this study.

The anthracnose disease occured due to heavy rainfall in the first year adversely affected the development of plants and reduced the 100 grain weight values compared to second year of the study. The effect of leonardite doses on 100 grain weight was found to be statistically significant for both years of the study. A lineer significant increase were observed for 100 grain weight by increasing application doses of leonardite for both years. Highest 100 grain weight values were $129.6 \mathrm{~g}$ and $131.7 \mathrm{~g}$ for first and second years, respectively, and were obtained by $1000 \mathrm{~kg} \mathrm{ha}^{-1}$ leonardite application (Table 3). Gürsoy (2016) and Mostofa and Akın (2017) found that leonardite increased the 100-grain weight.

Table 2: Averages and groups for plant height, first pod height and average number of pods per plant for different leonardite doses in 2017 and 2019.

\begin{tabular}{|c|c|c|c|c|c|c|}
\hline \multirow[b]{2}{*}{ Leonardite doses ( $\mathrm{kg} \mathrm{ha}^{-1)}$} & \multicolumn{2}{|c|}{ Plant height $(\mathrm{cm})$} & \multicolumn{2}{|c|}{ First pod height $(\mathrm{cm})$} & \multicolumn{2}{|c|}{$\begin{array}{l}\text { Pod number per } \\
\text { plant (piece plant }{ }^{-1} \text { ) }\end{array}$} \\
\hline & 2017 & 2019 & 2017 & 2019 & 2017 & 2019 \\
\hline Control & $45.7 \mathrm{e}$ & $47.7 \mathrm{e}$ & $10.1 \mathrm{c}$ & $11.0 \mathrm{~d}$ & $5.03 \mathrm{f}$ & $5.23 \mathrm{e}$ \\
\hline 200 & $46.5 \mathrm{e}$ & $48.6 \mathrm{e}$ & $10.5 \mathrm{c}$ & $11.2 \mathrm{~d}$ & $5.76 \mathrm{e}$ & $6.13 \mathrm{~d}$ \\
\hline 400 & $48.7 \mathrm{~d}$ & $53.4 \mathrm{~d}$ & $10.5 \mathrm{c}$ & $11.9 \mathrm{c}$ & $6.13 \mathrm{~d}$ & $6.77 \mathrm{c}$ \\
\hline 600 & $50.5 \mathrm{c}$ & $57.9 \mathrm{c}$ & $12.0 \mathrm{~b}$ & $12.4 \mathrm{bc}$ & $6.53 c$ & $7.07 \mathrm{c}$ \\
\hline 800 & $54.6 \mathrm{~b}$ & $58.9 \mathrm{~b}$ & $12.3 \mathrm{ab}$ & $12.9 a b$ & $7.03 \mathrm{~b}$ & $7.57 \mathrm{~b}$ \\
\hline 1000 & $60.0 \mathrm{a}$ & $61.3 \mathrm{a}$ & $12.7 \mathrm{a}$ & $13.2 \mathrm{a}$ & $7.43 \mathrm{a}$ & $8.04 \mathrm{a}$ \\
\hline Mean & 51.0 & 54.6 & 11.4 & 12.1 & 6.30 & 6.80 \\
\hline $\operatorname{LSD}_{(0.05)}$ & 3.004 & 2.023 & 1.400 & 1.472 & 0.576 & 1.061 \\
\hline
\end{tabular}

Different letters in the rows indicate significant differences according to LSD test $(P \leq 0.05)$.

Table 3: The effects of the applications on the number of seeds per pod, 100-grain weight and grain yield of the pod plant.

\begin{tabular}{|c|c|c|c|c|c|c|}
\hline \multirow[b]{2}{*}{ Leonardite doses $\left(\mathrm{kg} \mathrm{ha}^{-1}\right)$} & \multicolumn{2}{|c|}{ 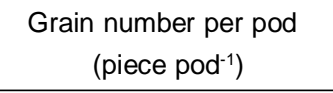 } & \multicolumn{2}{|c|}{100 Grain weight (g) } & \multicolumn{2}{|c|}{ Grain yield $\left(\mathrm{kg} \mathrm{ha}^{-1}\right)$} \\
\hline & 2017 & 2019 & 2017 & 2019 & 2017 & 2019 \\
\hline Control & $2.63 \mathrm{e}$ & $2.93 \mathrm{c}$ & 115.6 e & $121.2 \mathrm{e}$ & 1659 e & $1708 \mathrm{f}$ \\
\hline 200 & $2.93 \mathrm{~d}$ & $3.03 \mathrm{c}$ & $117.0 \mathrm{~d}$ & $121.5 \mathrm{e}$ & $1685 \mathrm{~d}$ & $1718 \mathrm{e}$ \\
\hline 400 & $3.13 \mathrm{c}$ & $3.43 \mathrm{~b}$ & $117.7 \mathrm{~d}$ & $123.1 \mathrm{~d}$ & $1709 \mathrm{c}$ & $1740 \mathrm{~d}$ \\
\hline 600 & $3.17 \mathrm{c}$ & $3.57 \mathrm{~b}$ & $122.6 \mathrm{c}$ & $126.0 \mathrm{c}$ & $1719 \mathrm{bc}$ & $1757 \mathrm{c}$ \\
\hline 800 & $3.33 \mathrm{~b}$ & $3.83 \mathrm{a}$ & $124.6 \mathrm{~b}$ & $126.8 \mathrm{~b}$ & $1726 \mathrm{~b}$ & $1772 \mathrm{~b}$ \\
\hline 1000 & $3.77 \mathrm{a}$ & $4.03 \mathrm{a}$ & $129.6 \mathrm{a}$ & $131.7 \mathrm{a}$ & 1769 a & $1808 \mathrm{a}$ \\
\hline Mean & 3.16 & 3.47 & 121.2 & 125.1 & 1711 & 1751 \\
\hline $\operatorname{LSD}_{(0.05)}$ & 0.309 & 0.516 & 2.059 & 1.494 & 28.06 & 18.19 \\
\hline
\end{tabular}

Different letters in the rows indicate significant differences according to LSD test $(P \leq 0.05)$. 
Ergönül (2011) found that leonardite application reduced the 100-grain weight, Öktem et al. (2017) reported that the application of humic acid was not affective for the 100 grain weights. These differences in the studies may be sourced from the cultivars, applied leonardite types and doses, application methods and the differences in the climate and soil conditions.

The anthracnose disease occured due to heavy rainfall in the first year negatively affected the development of plants and reduced the grain yield values compared to second year of the study. The effect of leonardite doses on grain yield values were found to be statistically significant for both years of the study. A lineer significant increase were observed for grain yield by increasing application doses of leonardite for both years. Highest grain yield values were $1769 \mathrm{~kg} / \mathrm{ha}$ and $1808 \mathrm{~kg} / \mathrm{ha}$ for first and second years, respectively and were obtained by $1 \mathrm{t} /$ ha leonardite application (Table 3 ). Ergönül (2011), Öktem et al. (2017) and Öztürk (2010) reported increased grain yields with leonardite applications similar to this study.

\section{CONCLUSION}

As a result of the study, it was determined that the leonardite applications were found beneficial to increase grain yields and to improve yield components in broad beans under low input, semi-arid Mediterranean conditions on highlands of South Eastern Anatolia region of Turkey. In both years of the study, as the dose of leonardite increased from 0,200 , $400,600,800$ and $1000 \mathrm{~kg} \mathrm{ha}^{-1}$, plant height, first pod height, number of pods per plant, number of grains per pod, 100 grain weight and grain yield were also increased. Highest grain yield values were $1769 \mathrm{~kg} / \mathrm{ha}$ and $1808 \mathrm{~kg} / \mathrm{ha}$ for the first and second years, respectively and were obtained by $1000 \mathrm{~kg} \mathrm{ha}^{-1}$ leonardite application.

\section{REFERENCES}

AARI (2020). Aegean Agricultural Research Institute, Registered Variety Catalogue, İzmir, Turkey.

Akinremi, O.O., Janzen, H.H., Lemke, R.L. and Larney, F.J. (2000). Response of canola, wheat and green beans to leonardite additions. Canadian Journal of Soil Science. 80: 437-443.

Arbaoui, M., Balko, C. and Link, W. (2008). Study of faba bean (Vicia faba L.) winter-hardiness and development of screening methods. Field Crops Research. 106: 60-67.

Azcona, I., Pascual, I., Aguirreoleal, J., Fuentes, M., Gracia-Mina, J.M. and Sanchez Diaz, M. (2011). Growth and development of pepper are affected by humic substances derived from composted sludge. Journal of Plant Nutrition and Soil Science. 174: 916- 924

Barone, V., Bertoldo, G., Magro, F., Broccanello, C., Puglisi, I., Baglieri, A. and Stevanato, P. (2019). Molecular and morphological changes induced by Leonardite-based biostimulant in Beta vulgaris L. Plants. 8: 181-199.

Batanay, Ş. (2016). The effect of different organic fertilizers on yield and yield characteristics of safflower (Carthamus tinctorius L.) under calcareous soil conditions. Master Thesis, Yozgat Bozok University, Yozgat, Turkey, pp. 58.
Cao, Y., Wu, C., Wang, L., Chen, M., Zhao, H., Bian, X., Chen, Y. and Xia, L. (2017). Rotation of broad bean improves the soil quality of facility green house. Legume Research. 40: 710-715.

Crepon, K., Marget, P., Peyronnet, C., Carrouee, B., Arese, P. and Duc, G. (2010). Nutritional value of faba bean (Vicia faba L.) seeds for feed and food. Field Crops Research. 115: 329-339.

Ergönül, U. (2011). The effects of humic acid and leonardite on yield and yield components of sunflower (Helianthus annuus L.) cultivars. Master's Thesis. Ankara University, Ankara, Turkey, pp. 71.

Etemadi, F., Hashemi, M., Barker, A.V., Zandvakili, O.R. and Liu, X. (2019). Agronomy, nutritional value, and medicinal application of faba bean (Vicia faba L.). Horticultural Plant Journal. 5: 170-182.

Gürsoy, M. (2016). The effects of different humic acid doses on the quantitative and qualitative properties of spring rapeseed (Brassica napus ssp. oleifera L.) in Ankara conditions. Doctoral Thesis. Ankara University, Ankara, Turkey. pp. 93.

İmamoğlu, S. (2019). The effect of different leonardite applications on yield and quality of beans. Master Thesis, Bursa Uludağ University, Bursa, Turkey. pp. 77.

Karadavut, U., Kayış, S.A. and Keskin, İ. (2011). Determination of the relationships between grain yield and characteristics affecting yield in some broad bean (Vicia faba L.) genotypes. Anatolian Journal of Agricultural Sciences. 26: 30-35.

Kulikova, N.A., Abroskin, D.P., Badun, G.A., Chernysheva, M.G., Korobkov, V.I., Beer, A.S. and Perminova, I.V. (2016). Label distribution in tissues of wheat seedlings cultivated with tritium-labeled leonardite humic acid. Scientific Reports. 6: 1-10.

Lingaraju, N.N., Hunshal, C.S., Salakinkop, S.R. (2016). Effect of biofertilizers and foliar application of organic acids on yield, nutrient uptake and soil microbial activity in soybean. Legume Research. 39: 256-261.

Link, W., Hocking, T.J. and Stoddard, F.L. (2007). Evaluation of physiological traits for improving drought tolerance in faba bean (Vicia faba L.). Plant and Soil. 292: 205-217.

Mostofa, A.A.A., Akin, A. (2017). The effects of humic substance applications in different doses on yield and quality of Italia grape cultivar. COMU Journal of Agricultural Faculty. 5: 73-78.

Öktem, A., Nacar, A. and Öktem, A. (2017). The effect of the amount of humic acid applied to the soil as a liquid on yield and some yield components of red lentil plant (Lens culinaris Medic.). Journal of Field Crops Central Research Institute. 26: 119-124.

Özel, E.Z. (2011). The effect of leonardite organic material on nitrogen uptake of maize plant in soil with two different textures. Master Thesis, Namık Kemal University, Tekirdağ, Turkey, pp. 80.

Öztürk, E. (2010). The effects of different leonardite amounts on yield and yield components in organic corn cultivation. Master Thesis, Canakkale Onsekiz Mart University, Çanakkale, Turkey, pp. 70. 
Effects of Leonardite Application on Yield of Broad Beans (Vicia faba L.) under low input Rainfed Semi-arid Mediterranean...

Paolo, E.D., Garofalo, P. and Rinaldi, M. (2015). Irrigation and nitrogen fertilization treatments on productive and qualitative traits of broad bean (Vicia faba var. minor L.) in a Mediterranean environment. Legume Research. 38: 209-218.

Petrov, D., Tunega, D., Gerzabek, M.H. and Oostenbrink, C. (2017). Molecular dynamics simulations of the standard leonardite humic acid: Microscopic analysis of the structure and dynamics. Environmental Science and Technology. 51: 5414-5424.

Sakulthaew, C., Watcharenwong, A., Chokejaroenrat, C. and Rittirat, A. (2021). Leonardite-derived biochar suitability for effective sorption of herbicides. Water, Air and Soil Pollution. 232: 1-17.
Singh, A.K., Bharati, R.C. and Pedpati, A. (2013). An assessment of faba bean (Vicia faba L.) current status and future prospect. African Journal of Agricultural Research. 8: 6634-6641.

Singkham, J., Ditthakit, P. (2019). Effect of modified leonardite on growth and fruit yield of cucumber (Cucumis sativus L.). Journal of Advanced Agricultural Technologies. 6: 272275.

Sun, Q., Ding, W., Yang, Y., Sun, J. and Ding, Q. (2016). Humic acids derived from leonardite-affected growth and nutrient uptake of corn seedlings. Communications in Soil Science and Plant Analysis. 47: 1275-1282. 